\title{
Analisis Kecelakaan Lalulintas pada Area Black Spot Ruas Jalan Lintas Sumatra Duri - Pekanbaru Kabupaten Bengkalis
}

\author{
Naswandi wanto $^{1}$, Zulfikar Djauhari ${ }^{2}$, Ari Sandhyavitri ${ }^{3}$ \\ 1,2,3 Program Pasca Sarjana, Magister Teknik Sipil, Universitas Riau Kampus Bina Widya JL. HR Soebrantas KM 12,5 \\ Pekanbaru, Kode Pos 28293. \\ Email: naswandi.wanto6390@grad.unri.ac.id, zulfikr-dj@yahoo.com, ari.sandhyavitri@lecturer.unri.ac.id
}

\begin{abstract}
ABSTRAK
Keselamatan jalan merupakan salah satu penelitian bidang transportasi.Kecelakaan lalulintas menimbulkan masalah serius bagi masyarakat berupa biaya medis, biaya ekonomi (kerugian produktivitas), biaya kerusakan properti,serta biaya rasa sakit dan duka cita. Salah satu upaya untuk meningkatkan keselamatan transportasi yaitu dengan penentuan dan penanganan lokasi rawan kecelakaan lalu lintas. Metode yang digunakan untuk mengidentifikasi lokasi rawan kecelakaan yaitu metode pembobotan lokasi rawan kecelakaan untuk mengidentifikasi lokasi rawan kecelakaan dengan menggunakan metode Batas Kontrol Atas (BKA) dan Upper Control Limit (UCL) hasil analisis terdapat dua ruas jalan dengan jumlah angka ekivalen kecelakaan lebih besar dibandingkan nilai BKA dan nilai UCL dan diidentifikasi lokasi rawan kecelakaan lalu lintas adalah jalan lintas sumatera km112 dan km126. Hasil dari penelitian ini menunjukkan ketidak konsistenan desain geometri khususnya desain alinyemen horisontal segmen jalan yang ditinjau. Model yang dihasilkan menunjukkan bahwa tingkat kecelakaan akan turun jika radius tikungan lebih tinggi dari pada rata-rata radius tikungan dari segmen jalan tinjauan.
\end{abstract}

Kata kunci: Lokasi rawan kecelakaan, upper control limit, kecelakaan lalu lintas, angka ekivalen kecelakaan, konsistensi desain geometri.

\section{ABSTRACT}

Road safety is a complicated scientific field of transport research.Traffic accidents impose serious problems to society in terms of medical costs, economic costs (productivity losts), property damage costs, and human costs. One effort to improve transportation safety is by determining and handling the black spot locations. The method that used to identify black spot locations is the location weighting method prone to accidents to identify black spot locations using Upper Control Limit (UCL) method, based on the results of the analysis there are Two roads have accident number value greater than the upper control limit value and identified as a black spot location is the road crossing Sumatera $\mathrm{km} 112$ and $\mathrm{km}$ 126.The results show that most of the sections in the location studied is classified as inconsistence. It is also shown that accident frequency decreases when the radius of a given section is significantly higher than the average radius.

Keywords : Black spot, upper control limit, traffic accident, equivalent accident number,Geometric design consistency

\section{PENDAHULUAN}

Pembangunan infrastruktur pada Jalan Lintas Sumatra Duri - Pekanbaru memiliki nilai yang sangat strategis dalam mendukung perkembangan dan pertumbuhan ekonomi nasional. Namun dibalik manfaat besar yang diperoleh, ternyata muncul beberapa permasalahan yang berkaitan dengan pengelolaan infrastruktur jalan. Undang - Undang RI No. 22 tahun 2009 tentang Lalu Lintas dan angkutan Jalan Pada pasal 226 mengamanatkan kepada kita bahwa, untuk menciptakan keselamatan lalu lintas, perlu disusun program pencegahan kecelakaan lalu lintas, yang dalam pelaksanaanya perlu partisipasi para pemangku kepentingan, pemberdayaan masyarakat, penegakan hukum dan kemitraan global.
Ada beberapa faktor yang menyebabkan kecelakaan lalulintas antara lain faktor manusia yang mencakup pengemudi dan pejalan kaki (pengguna jalan), faktor prasarana yang mencakup jalan dan lingkungan jalan dan faktor sarana atau kendaraan.(Indriastuti, Fauziah, and Priyanto 2011)(Sumberbaru, Jbr, and Jbr 2009).

Kabupaten bengkalis tepatnya di kecamatan mandau dan pinggir terdapat jalan lintas sumatra merupakan jalur utama jalur akses penting keluar masuk kendaraan dari Dumai, Duri, Baganbatu, Pekanbaru, Medan maka segmen jalan ini mempunyai peranan yang sangat penting sebagai jalur transportasi darat dimana banyak akses hilir mudik baik kendaraan pribadi, kendaraan barang, maupun wisatawan yang melewati jalur yang memiliki tingkat mobilitas kendaraan yang sibuk. 


\section{TINJUAN PUSTAKA}

Secara umum, keselamatan infrastruktur jalan dapat diartikan sebagai upaya dalam menanggulangi kecelakaan yang terjadi di jalan raya (road crash), yang tidak hanya disebabkan oleh faktor kondisi kendaraan maupun pengemudi, namun disebabkan pula oleh banyak faktor, antara lain:

(1) Kondisi alam (cuaca)

(2) Desain ruas jalan (alinyemen vertikal dan horizontal)

(3) Jarak pandang pengemudi

(4) kondisi kerusakan perkerasan

(5) kelengkapan rambu atau petunjuk jalan

(6)Pengaruh budaya dan pendidikan masyarakat sekitar jalan

Bahkan peraturan / kebijakan lokal yang berlaku, dapat secara tidak langsung memicu terjadinya kecelakaan di jalan raya, misalnya penetapan lokasi sekolah dasar di tepi jalan arteri (Mulyono dkk, 2009. Hasil penelitian yang lebih baru tidak hanya memfokuskan pada kesalahan manusia sebagai faktor utama penyebab kecelakaan lalu lintas. Pemikiran ini didasari bahwa kesalahan manusia lebih banyak dipicu oleh kondisi sistem lalu lintas dan jalan raya yang pada saat-saat tertentu tidak dapat diantisipasi oleh pengguna jalan. Sebagai contoh, penelitian di Universitas Leeds tahun 1989 (Carsten, 1989) atas kecelakaan di daerah perkotaan mengkategorikan lebih jauh faktor kesalahan manusia yang dipicu oleh keterbatasan jarak pandang ketika mengemudikan kendaraan yaitu hampir 30\% dari $45 \%$ kasus yang disebabkan faktor manusia.

Secara statistik, jalan jarang disalahkan sebagai faktor penyebab. Berbagai analisis atas lokasi kejadian kecelakaan menunjukkan bahwa kesalahan manusia lebih banyak terjadi pada tipe-tipe geometrik jalan tertentu. Bahkan dalam kasus kecepatan tinggi yang sering dianggap sebagai penyebab langsung terjadinya kecelakaan, didapat kenyataan bahwa kecepatan tersebut dipicu secara jelas oleh tipe-tipe lokasi tertentu (Weller, et al., 2006). Bahkan OECD (1999) telah sampai pada kesimpulan bahwa sistem jaringan jalan luar kota memiliki karakteristik inheren yang secara signifikan berkontribusi terhadap tingginya resiko dan angka kecelakaan. Berkaitan dengan hal tersebut, Rasmussen (1987) menyimpulkan bahwa untuk meningkatkan keselamatan maka sudut pandang yang lebih bermanfaat adalah dengan menggambarkan kesalahan-kesalahan manusia sebagai kejadian ketidaksesuaian antara manusia dengan mesin kendaraan atau manusia dengan tugasnya. Apabila ketidak sesuaian ini sering terjadi atau terjadi secara sistematik, maka kemungkinan sebagai narasumber dalam penelitian mengenai analisis kecelakan lalu lintas pada area besar penyebabnya adalah kesalahan desain jalan. Lebih jauh dikatakan analisis atas laporan kecelakaan mengesankan bahwa aksi manusia dikategorikan sebagai kesalahan karena perbuatan itu dilakukan di dalam lingkungan yang 'tidak ramah' atau 'kejam' dikatakan sebagai lingkungan yang 'tidak ramah', karena hampir tidak pernah tersedia kemungkinan bagi seseorang untuk memperbaiki efek dari kekurangsesuaian kinerjanya sebelum dia menerima akibat yang tidak diinginkan (Rasmussen, 1987). Berdasarkan sudut pandang ini, maka masalah keselamatan lalu lintas bukan lagi masalah kesalahan pengemudi ataupun pengguna jalan, namun lebih pada kesalahan sistem lalu lintas (termasuk infrastruktur jalan) yang memicu terjadinya kesalahan-kesalahan manusia tersebut. Hal tersebut juga didukung hasil penelitian Mulyono,et al.(2008) yang menyimpulkan bahwa tanggung jawab yang lebih besar kini berada pada pundak para penyelenggara jalan yaitu perencana sistem jalan raya dan pengatur sistem lalu lintas yang harus mampu menciptakan indikator kuantitatif dalam monitoring dan evaluasi beberapa defisiensi keselamatan akibat penyimpangan standar teknis yaitu geometrik, perkerasan dan harmonisasi perlengkapan jalan sehingga dapat menetapkan kategori potensi kecelakaan pada lokasi jalan tertentu.

\section{METODE PENELITIAN \\ 1. Pendekatan Penelitian}

Penelitian ini merupakan analisis kecelakaan lalu lintas pada area black spot ruas jalan lintas Sumatera Duri - Pekanbaru Kabupaten Bengkalis yang meneliti tentang area black spot, alinyemen horizontal, LHR, kondisi jalan, kecepatan lalu lintas dan pengguna jalan lintas Sumatera Duri Pekanbaru Kabupaten Bengkalis.

\section{Tempat dan waktu penelitian}

Penelitian ini dilakukan di kecamatan mandau dan kecamatan pinggir tepat nya di jalan lintas Sumatera Duri - Pekanbaru Kabupaten Bengkalis yang teridentifikasi daerah rawan kecelakaan lalu lintas berdasarkan data sekunder yang di keluarkan oleh satuan lalu lintas Polres Bengkalis selama lima tahun terakhir dari tahun $2013-2017$.

\section{Teknik pengumpulan Data}

Dalam penelitian ini teknik dan cara pengumpulan data yang dignakan yaitu berupa wawancara langsung kepada Narasumber terdapat delapan unsur pihak yang diharapkan dapat berperan

black spot ruas jalan lintas Sumatera Duri Pekanbaru Kabupaten Bengkalis yaitu kasat lantas 
Polres Bengkalis, Kanit laka lantas Polres Bengkalis, Penyidik pembantu Unit laka lantas Polres Bengkalis, Dinas Perhubungan Kabupaten Bengkalis.

Selanjutnya yang tidak kalah pentingnya narasumber dipilih dari korban kecelakaan lalu lintas, dilanjutkan dengan petugas medis rumah sakit umum kecamatan mandau dan masyarakat sebagai narasumber yang kebetulan berada atau mengetahui tentang kejadian, peristiwa yang berkaitan dengan kecelakaan lalu lintas di sekitar wilayah studi.Semua narasumber dipilih berdasarkan keterlibatan dalam penanganan kecelakaan lalu lintas di Kabupaten Bengkalis. Jumlah dan ragam narasumber bisa berkembang sesuai dengan kondisi/kebutuhan dilapangan, hasil survei di lapangan terhadap 40 responden yaitu orang yang terlibat langsung di dalam penanganan kecelakaan lalu lintas seperti pihak kepolisian, dinas perhubungan, petugas medis, korban kecelakaan lalu lintas dan masyarakat setempat di lokasi study.

\section{HASIL DAN PEMBAHASAN}

Data yang di peroleh dari Polres Bengkalis kecelakaan yang terjadi pada Jalan lintas sumatera Duri - Pekanbaru yang memiliki tingkat kecelakaan yang relatif tinggi dari 69 ( enam puluh sembilan) segmen ruas jalan lintas sumatra Duri Pekanbaru yang merupakan lokasi terjadinya kecelakaan lalulintas selama lima tahun dari tahun 2013 s.d 2017 Jumlah perkembangan kecelakaan lalu lintas yang terjadi selama periode lima tahun pada jalan lintas sumatra Duri - Pekanbaru sebanyak 538 kasus kecelakaan dengan klasifikasi korban kecelakaan dapat dilihat pada Gambar 2 di bawah ini :

Gambar 2 : Grafik frekuensi kecelakaan berdasarkanKorban kecelakaan

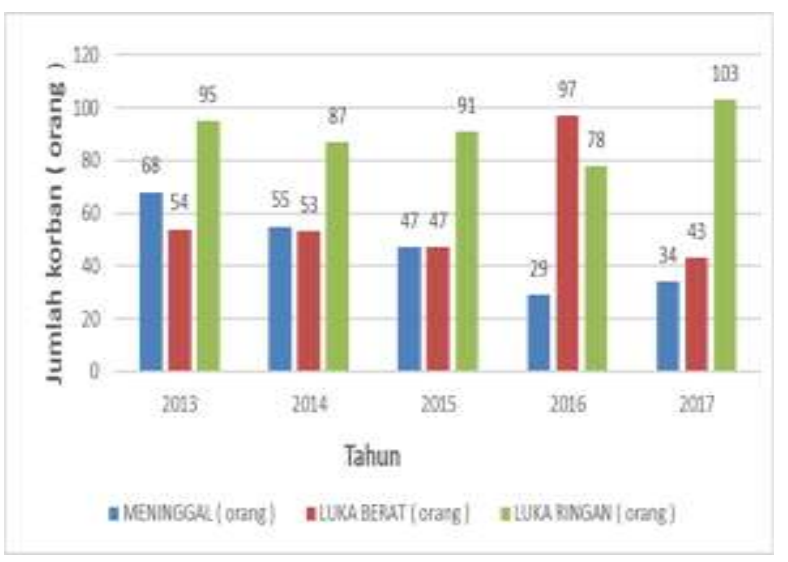

Dari hasil nalisis data terdapat beberapa segmen ruas Jalan lintas Sumatera Duri Pekanbaru yang merupakan Black Spot dengan menggunakan metode pembobotan lokasi rawan dengan menggunakan metode yaitu Parameter Angka
Ekuivalen ( AEK), Batas contol atas ( BKA), Upper Control Limit ( UCL ) maka di dapatkan lokasi Black Spot pada Jalan lintas sumatra Duri - Pekanbaru terdapat pada ruas Jalan lintas sumatera Duri Pekanbaru km 112 dan km 126 dapat di lihat pada Gambar di bawah ini:

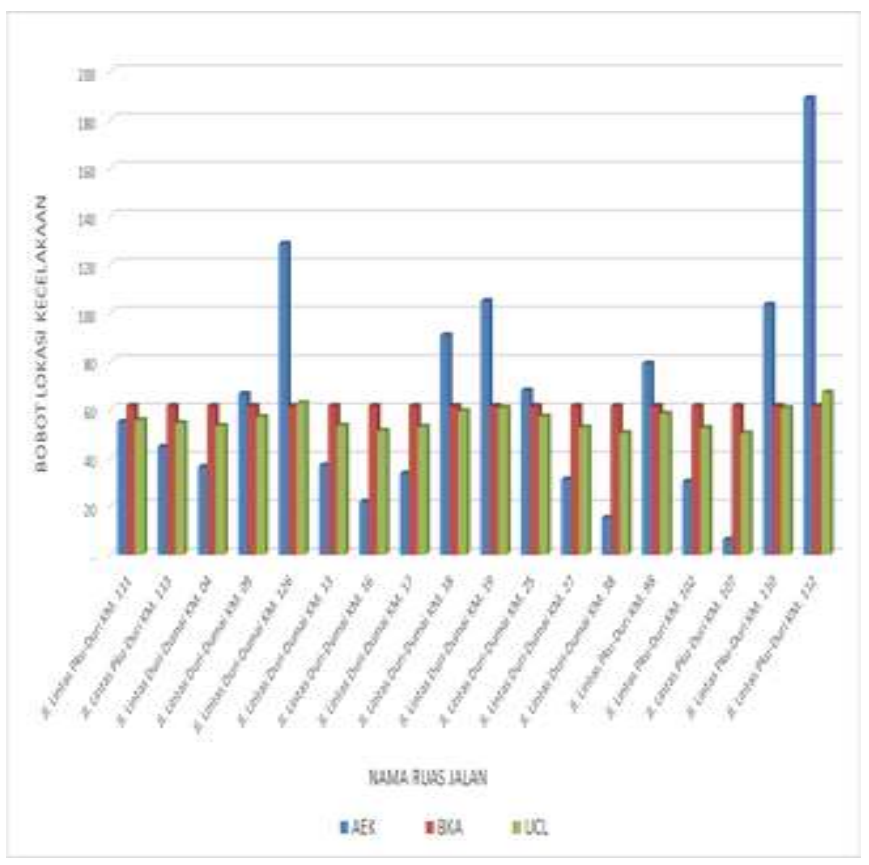

Gambar 3 : Peringkatan lokasi kecelakaan

\section{Identifikasi Accident Rate Berdasarkan Black Spot}

Dari hasil perhitungan tingkat kecelakaan diatas maka dapat diidentifikasi ke dua ruas jalan tersebut kedalam ruas jalan tergolong black spot. Setelah itu dapat dihitung tingkat kecelakaannya sesuai Persamaan di bawah ini dengan memasukkan nilai kecelakaan rata-rata per tahun dan nilai LHR rata-rata yang sudah didapat untuk mencari accident rate berdasarkan black spot seperti persamaan berikut ini

TKL $($ Accident Rate $)=\frac{J K R X 1.000 .000}{(V X 365)}$

TKL = jumlah kecelakaan (accident rate)

$\mathrm{JKR}=$ Jumlah kejadian kecelakaan tahunan

$\mathrm{V}=$ Volume lalu LIntas (Kend/hari)

Berdasarkan hasil perhitungan dengan menggunakan persamaan Accident Rate dengan ini dapat dilihat bahwa tingkat kecelakaan tertinggi terjadi pada km 112 dengan tingkat accident rate 0.60 . Sedangkan nilai Accident rate yang terendah adalah pada $\mathrm{km}$ 126 yaitu 0.45 bisa di lihat pada tabel 4.5 di bawah ini. Dalam penelitian ini untuk lokasi penelitian di 
areah black spot hanya lakukan pada Ruas jalan yang memiliki nilai Accident rate yang tertinggi saja.

Tabel 1. Identifikasi Accident Rate

\begin{tabular}{|l|l|l|l|l|}
\hline No & $\begin{array}{l}\text { Location } \\
\text { (STA) }\end{array}$ & Accidents & $\begin{array}{l}\text { Trafic } \\
\text { Volume } \\
\text { (vehicle) }\end{array}$ & $\begin{array}{l}\text { Accident } \\
\text { Rate } \\
\text { ( TKL ) }\end{array}$ \\
\hline 1 & KM 126 & 9 & 54.769 & 0.45 \\
\hline 2 & KM 112 & 12 & 54.769 & 0.60 \\
\hline
\end{tabular}

\section{Perhitungan Weighted Severity Index}

Data kecelakaan ini dianalisis dengan menggunakan metode weightity severity index (WSI). "Metode keparahan ini menetapkan skor berdasarkan jumlah dan tingkat keparahan kecelakaan di lokasi tertentu di jalan dalam minimum 3 tahun terakhir". Jumlah korban menjadi tiga tingkat keparahan seperti kematian, cedera serius dan cedera ringan Bobot dari kecelakaan didasarkan pada karakteristik kecelakaan seperti lokasi kecelakaan, jumlah orang yang terluka dan jumlah orang yang meninggal karena kecelakaan.

Tabel 2 Analisa weighted severity index (WSI )

\begin{tabular}{|c|c|c|c|c|c|c|c|}
\hline NO & TAHUN & STA & $\begin{array}{l}\text { JUMLAH } \\
\text { KASUS }\end{array}$ & MD & LB & LR & $\begin{array}{c}\text { WSI }=(5 \\
\times \mathrm{k}) \div \\
(3 \times \mathrm{gi}) \\
+(1 \times \mathrm{NI})\end{array}$ \\
\hline 1 & \multirow{2}{*}{$\begin{array}{c}2013 \\
\text { S.D } \\
2017\end{array}$} & $\begin{array}{l}\text { JI. Lintas Duri- } \\
\text { Dumai KM. } 126\end{array}$ & 9 & 8 & 5 & 5 & 60 \\
\hline 2 & & $\begin{array}{l}\text { Jl. Lintas PKu- } \\
\text { Duri KM. } 112\end{array}$ & 12 & 5 & 12 & 29 & 90 \\
\hline \multicolumn{3}{|c|}{ Jumiah } & 21 & 13 & 17 & 34 & 150 \\
\hline
\end{tabular}

Ket : K= jumlah korban

$$
\mathrm{Gi}=\text { jumlah } \mathrm{LB}
$$

$\mathrm{Ni}=$ jumlah $\mathrm{LR}$

Berdasarkan analisa yang dilakukan dengan dengan menggunakan teori weighted severity index dan accident rate dan survei di lapangan dengan menganalisa gambar rencana dari Kementrian pekerjaan umum dengan menggunakan Autocad 2017 maka di dapatkan tiga tikugan yang merupakan black site yang terdiri dari sta $\mathrm{km} 112$ terdapat satu tikungan, sta $\mathrm{km} 126$ terdapat dua tikunga yaitu di sta $126+153$ dan sta $\mathrm{km} \mathrm{126+296}$ yang mana loksi tersebut memiliki kejadian kecelakaan yang relatif tinggi.Dari tiga tikungan tersebut dan berdasrkan hasil analisa Alinyemen Horizontal jalan yang merupakan proyeksi sumbu/as jalan pada bidang horizontal (peta) yang terdiri dari bagian lurus (tangent) dan bagian lengkung (curve) jalan. Hasil rekapitulasi dari analisa Alinyemen Horizontal dapat di lihat pada Tabel 3 di bawah ini.

\section{Analisia Jarak Pandang Henti}

Berdasarkan perhitungan terhadap jarak pandang henti di atas pada tiga tikungan yaitu pada tikungan pertama pada sta $\mathrm{km} 112+120$ Jarak pandang henti yang terukur di lapangan 135 meter sementara jarak pandang minimum sesuai dengan kententuan dari binamarga dengan keceaptan $80 \mathrm{~km}$ / jam sebesar 120 meter jadi jarak pandang di lapangan lebih besar dari jarak pandang minimum yang telah di tentukan oleh Bina marga dan dapt di simpulkan penyebab kecelakaan lalulintas pada lokasi tersebut di indikasikan bukan di sebabkan oleh jarak pandang henti. Pada tikungan tikungan ke dua dan ketiga pada $\mathrm{km} 126+153$ dan sta $\mathrm{km} 126+296$ masing masing kecepatan rencana nya $80 \mathrm{~km} /$ jam dengan melihat ketentuan dari Binamarga di dapatkan jarak pandang pada tikungan ke dua dan ke tiga sebesar 132 meter sementara di lapangan terukur jarak pandang pada tikungan ke dua sebesar 68 meter dan pada tikungan ke tiga sebesar 65 meter jadi jarak pandang di lapangan lebih kecil dari jarak pandang minimum yang telah di tentukan oleh Bina marga sebesar 120 meter, sehingga berdasarkan hasil analisa terhadap jarak pandang henti pada tikungan ke dua dan ke tiga terindikasi salah satu penyebab terjadinya kecelakaan lalulintas pada lokasi tersebut adalah terbatasnya jarak padang pengemudi kendaraan.

\section{Analisis daerah bebas samping tikungan}

Daerah bebas samping yang di maksud untuk memberi kemudahan padangan pada tikugan dengan membebaskan objek - objek sejauh E ( meter ). Berdasarkan hasil survei di lapangan dan nilai tabel dari binamarga untuk ke tiga tikungan tersebut memiliki nilai yang kurang dari nilai minimum yang di syaratkan sehingga pada ke tiga lokasi tersebut diatas tingkat kecelakaan lalulintas relatif tinggi salah satu di sebebkan oleh terbatas nya jarak pandang pengemudi di karenakan daerah bebas samping pada tikungan tidak memenuhi nilai yang di persyaratkan oleh Bina marga.

\section{Analisis super elevasi}

Superelevasi adalah kemiringan penuh melintang permukaan jalan pada bagian lengkung, Kemiringan melintang jalan (superelevasi) pada lengkung horizontal bertujuan untuk memperolah komponen berat kendaraan guna mengimbangi gaya sentrifugal. Berdasarkan hasil analisa diatas terjadi ketidak sesuaian untuk nilai elevasi maksimum yang seharusnya elevasi pada tikungan sebesar $8 \%$ di daearah jalan antar kota sementara nilai elevasi di lapangan lebih kecil dari nilai minimum elevasi didaerah perkotaan sebesar $6 \%$,tentu saja kendaraan yang melawati di tikungan tersebut dengan kecepatan $80 \mathrm{~km} /$ jam tidak bisa mengimbangi gaya 


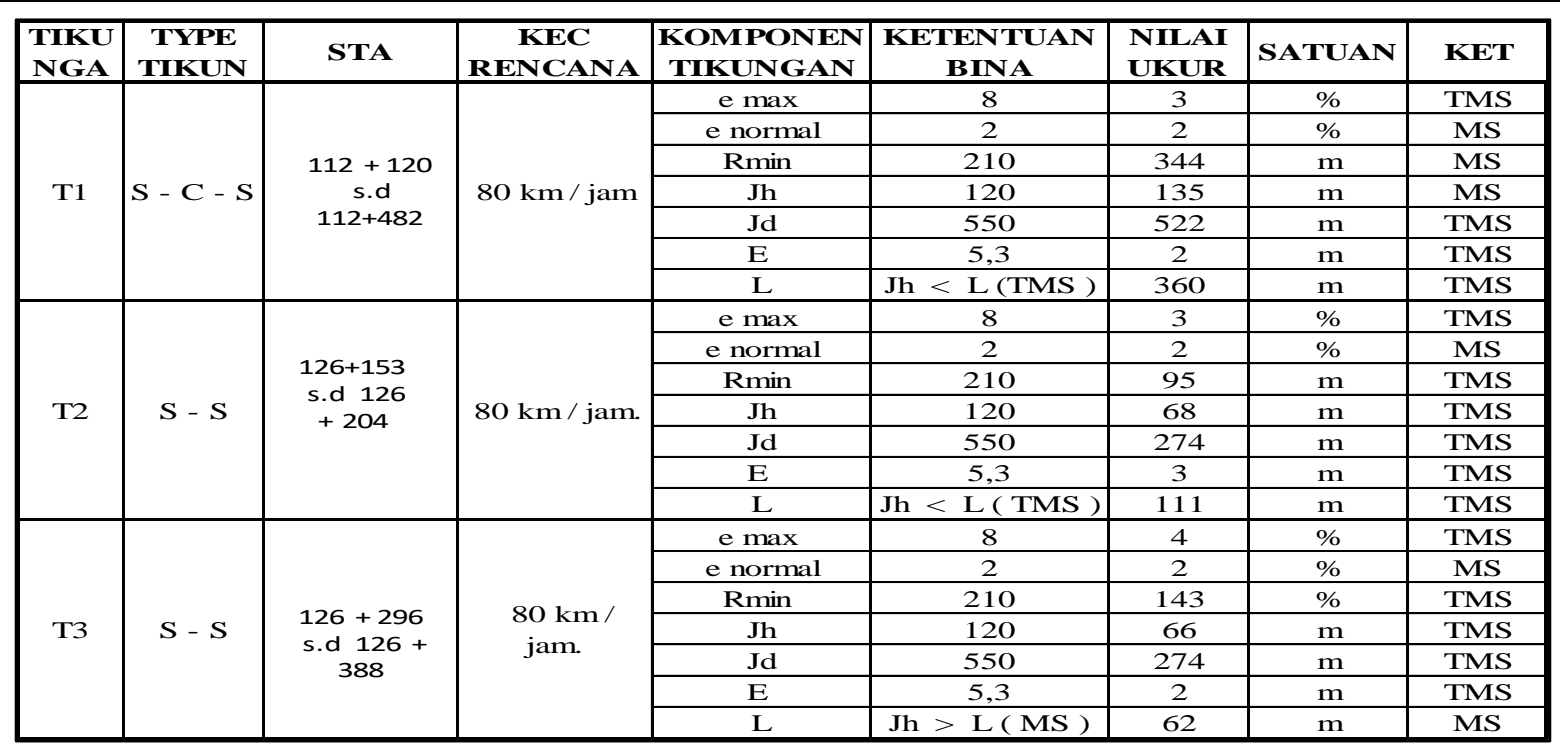

sentrifugal yang dialami kendaraan selama berjalan di tikungan.

\section{Analisa Radius tikungan}

Dari hasil analisa dan perhitungan yang bisa di lihat pada tabel 4 diatas setelah dilakukan survei dan perhitungan yang mengikuti ketentuan dari bina marga ( tabel ) sebagai berikut :

1. Tikungan 1 sta112 +120 nilai Radius tikungan dengan kecepatan rencana $80 \mathrm{~km} /$ jam sesuai kententuan Binamarga Radius minumum sebesar 210 meter di lapangan telah dilakkan pengukuran dan perhitungan di dapatkan nilai Radius 344 meter, R Min > R lapangan tikungan pertama menenuhi persyaratan.

2. Tikungan 2 sta126 +153 Radius tikungan dengan kecepatan rencana $80 \mathrm{~km} /$ jam sesuai kententuan Binamarga Radius minumum sebesar 210 meter di lapangan telah dilakkan pengukuran dan perhitungan di dapatkan nilai Radius 95 meter, $\mathrm{R}$ Min < $\mathrm{R}$ lapangan tikungan kedua tidak menenuhi persyaratan.

3. Tikungan 3 sta126 + 296 Radius tikungan dengan kecepatan rencana $80 \mathrm{~km} /$ jam sesuai kententuan Binamarga Radius minumum sebesar 210 meter

1. Lokasi sta $112+120$

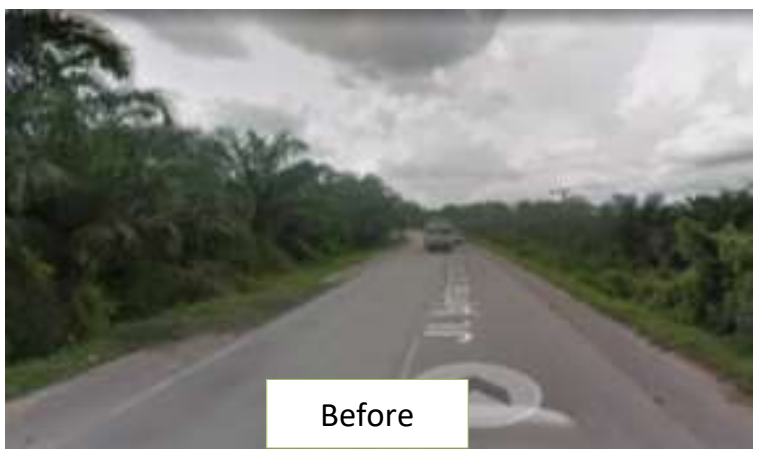

di lapangan telah dilakkan pengukuran dan perhitungan di dapatkan nilai Radius 143 meter, $\mathrm{R}$ Min $<\mathrm{R}$ lapangan tikungan ketiga tidak menenuhi persyaratan.

\section{Rekomendasi Teknis}

Konsistensi dalam merencanakan alinyemen horisontal jalan, khususnya dalam hal penentuan radius tikungan, harus mulai diperhatikan. Evaluasi terhadap alinyemen horisontal yang telah ada harus dilakukan, mengingat pengaruhnya pada tingkat kecelakaan. Terhadap prasarana jalan yang meliputi kondisi jalan beserta kelangkapan fasilitas jalan ada beberapa segmen jalan yang menurut peneliti harus dibenahi dan dilakukan manajemen dan rekayasa lalu lintas terhadap perlengkapan fasilitas jalan (Rambu, Marka, guardrail, delineator dll) sesuai dengan peraturan menteri perhubungan republik indonesia nomor PM 13 tahun 2014 tentang rambu lalu lintas dan peraturan menteri pekerjaan umum nomor : 19/ prt / m / 2011 tentang persyaratan teknis jalan dan kriteria perencanaan teknis jalan diantaranya sebagai berikut:

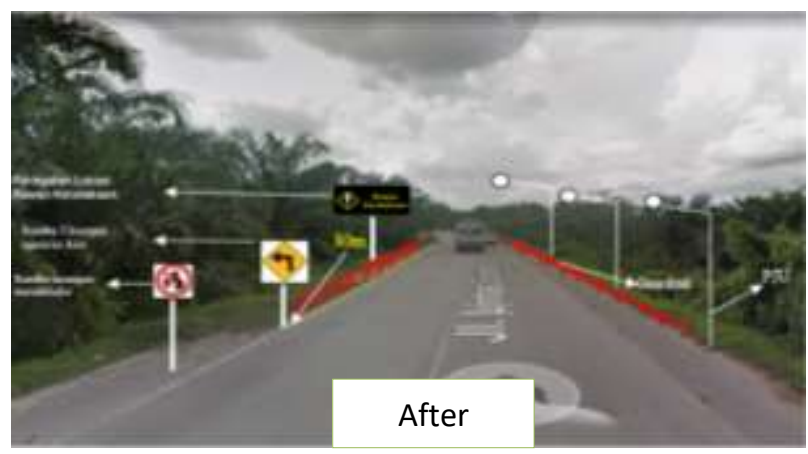




\section{Lokasi sta $126+153$}
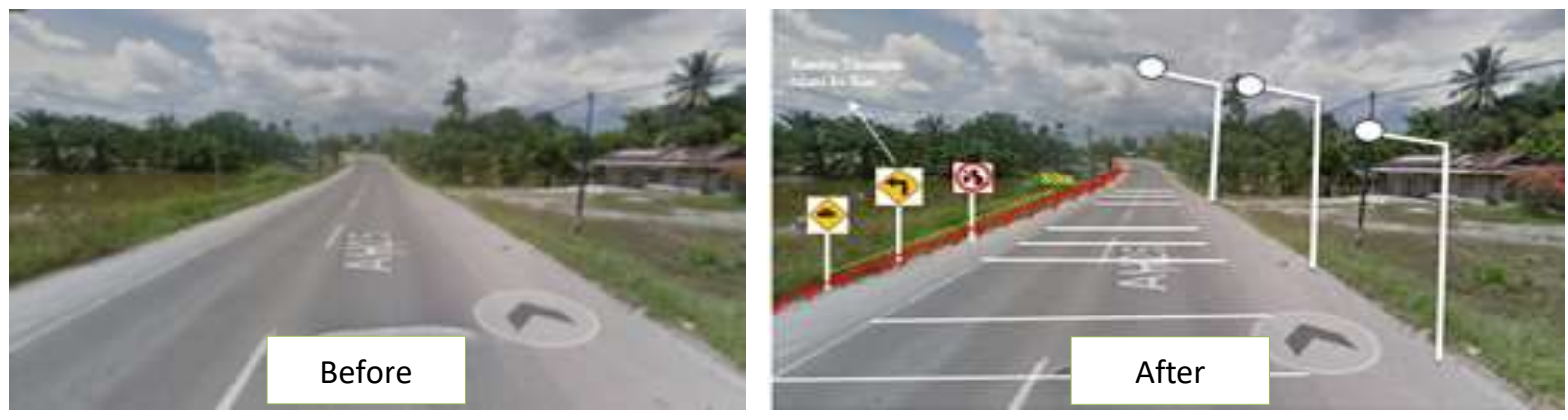

\section{Lokasi sta $126+296$}

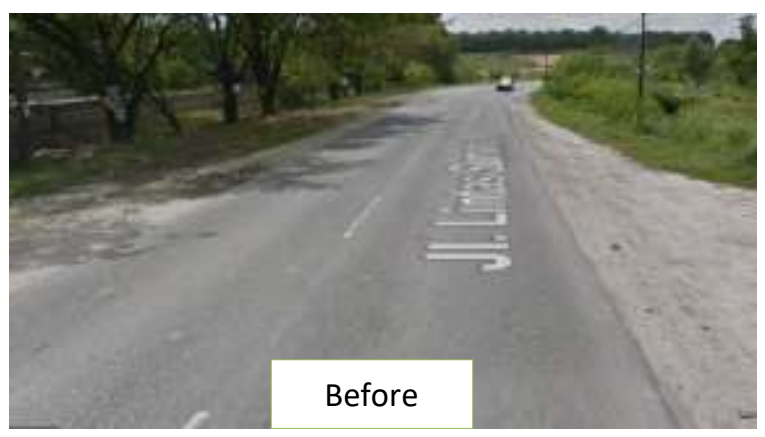

\section{Kesimpulan}

Berdasarkan hasil analisis data dan survei lapangan maka dapat di simpulkan sebagai berikut :

1. Black spot berada pada segmen jalan lintas sumatera Duri - Pekanbaru yaitu :

$$
\begin{array}{ll}
\text { a. } & \text { KM } 112 \text { nilai AEK }=189>\text { nilai BKA } \\
=59,1 \text { dan UCL }>\text { BKA }=65,1 \\
\text { b } & \text { KM } 126 \text { nilai AEK }=129>\text { nilai BKA } \\
=59,1 \text { dan UCL }>\text { BKA }=60,1
\end{array}
$$

Untuk black site ( titik rawan kejadian kecelakaan yang ditinjau pada ruas jalan yang diamati ) berada pada STA

$\mathrm{Km} \quad 112+120$ dan KM $126+153, \quad \mathrm{Km}$ $126+296$ yang tidak memenuhi persyaratan teknis sesuai dengan standar Binamarga yaitu yang memiliki radius lebih kecil dibanding radius standar, super elevasi kecil dibanding standar elevasi, daerah bebas samping yang lebih kecil di banding standar daerah bebas samping, Jarak pandang henti dan mendahului yang tidak sesuai dengan kondisi jalan.

2. Kondisi penyebab kecelakaan yang paling tinggi adalah

a. Faktor manusia sebesar $93 \%$ terdiri dari melebihi batas kecepatan 49\%

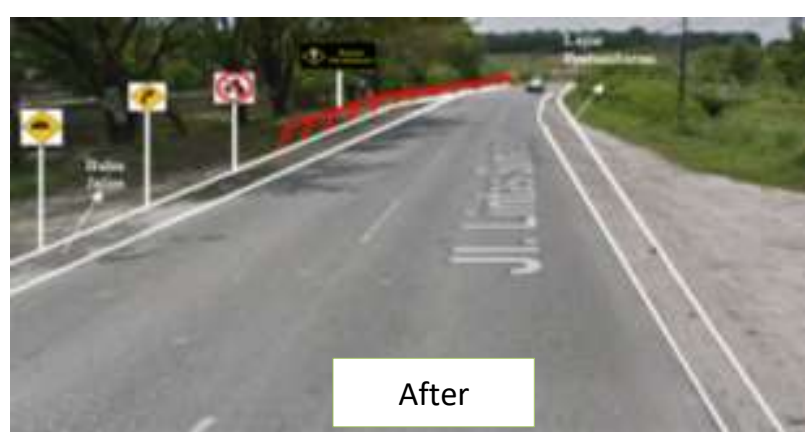

diikuti dengan lengah $38 \%$, lelah $2 \%$,tidak tertib $4 \%$

b. Faktor kendaraan sebesar $4 \%$ terdiri dari rem tidak berfungsi $1 \%$, kemudi kurang baik $1 \%$, lampu depan tidsk menyala $1 \%$.

c. Faktor jalan raya sebesar $4 \%$ terdiri dari jalan rusak $1 \%$, jalan berlubang $1 \%$,tidak ada penerangan jalan ( lampu ) $1 \%$, tikungan tajam $1 \%$.

3. Rekomendasi perbaikan geometrik dan akses jaringan jalan di jalan lintas Sumatera Duri-Pekanbaru pada KM $112+120, \mathrm{KM}$

$126+153$ dan KM $126+296$ berupa perbaikan jari -jari tikungan, elevasi jalan, perbaikan derah bebas tikungan dan perbaikan serta penambahan perlengkapan jalan raya.

\section{Saran}

Berikut merupakan beberapa saran yang penulis berikan untuk arah kebijakan khususnya mengurangi angka kecelakaan di wilayah studi.

1. Diperlukan pemenuhan persyaratan standar jalan agar jalan menjadi jalan yang berkeselamatan (perbaikan alinyemen 
horizontal, perkerasan jalan, derah bebas samping, dan bahu jalan) utuk meminimalisir kecelakaan yang disebabkan oleh elevasi jalan dan jarak pandang terbatas bisa di beri rambu lalu lintas seperti Tikungan, dilarang mendahului, daerah rawan kecelakaan, batas maksimal kecepatan.

2. Pelaksanaan kegiatan pengadaan dan pemasangan fasilitas perlengkapan jalan yang meliputi rambu-rambu lalu lintas, marka jalan, lampu penerangan jalan, delineator dan guardrail.

3. Pada kondisi tertentu dapat melakukan kegiatan manajemen dan rekayasa lalu lintas yang bersifat permanen maupun sementara terhadap sistem pergerakan kendaraan di wilayah studi.

4. Instansi terkait Kepolisian dan Dinas Perhubungan Kabupaten Bengkalis disarankan untuk melakukan sosialisasi, pembinaan terhadap pengemudi yang berkeselamatan serta peningkatan penegakan hukum dalam hal penyelenggaraan lalu lintas.

5. Meningkatkan peran dan fungsi Forum LLAJ Kabupaten Bengkalis sebagai wadah menganalisis permasalahan, meningkatkan kualitas pelayanan dan menemukan solusi dalam penyelenggaraan lalu lintas dan angkutan jalan (Instansi Dishub, PU, Kepolisian dan Bappeda).

\section{DAFTAR PUSTAKA}

Mulyono, A. T., Kushari B., Agustin J., 2008, Monitoring and evaluating infrastructure safety deficiencies towards integrated road safety improvement in Indonesia, Proceedings. Australasian Road Safety Research, Policing and Education Conference, ISBN 1876346566

Weller, G., chlag, B., Gatti, G., Jorna, R., van de Leur, M., 006, Human Factors in Road Design - Sate of the Art and Empirical Evidence, Road Infrastructure Safety Protecti Core Research and Development for Road Safety in Europe; Increasing Safety and Reliability of Secondary Roads for a

Sustainable Surface Transport (RIPCORDISEREST).

Carsten, O., 1989, Urban Accidents: Why do They Happen?, UK: AA Foundation for Road Safety Research, Basingstoke.

Bolla, Margareth Evelyn, Yunita A. Messah, and Michal M. Bunga Koreh. 2013. "Analisis Daerah Rawan Kecelakaan Lalu Lintas (Studi Kasus Ruas Jalan Timur Raya Kota Kupang).” Jurnal Teknik Sipil II (2): 147-56.

Mulyono, A.T., 2009, Sistem Keselamatan Jalan untuk Mengurangi Defisiensi Infrastruktur Jalan Menuju Jalan Berkeselamatan,Prosiding Konferensi Nasional Teknik Sipil-3 (Konteks-3), ISBN 927-979-15429-3-7, Jakarta

Kepolisian Resort Bengkalis, 2015.Data Kecelakaan Lalu Lintas 2013-2017,Kabupaten Bengkalis.

Agus Sumarsono1), Florentina Pungky Pramesti2), Djoko Sarwono3), Juli 2010, Media Teknik Sipil, Volume X,halaman 91, ISSN 14120976

Rasmussen, J, 1987, The Definition of Human Error and a Taxonomy for Technical System Design, dalam New Technology and Human Error, Chicester: John Wiley \& Sons. Bina Marga, JALAN No.038/T/BM/1997, Sepetember 1997,Tata cara Perencanaan Geometrik Jalan Antar Kota, Jakarta ,Departemen pekerjaan umum.

Direktorat Jenderal Bina Marga, 2014 Panduan Kapasitas Jalan Indonesia (PKJI) Kementerian Pekerjaan Umum, Jakarta

Anderson, I. B., Bauer, K. M., Harwood, D. W., and Fitzpatrick, K. 1999. "Relationship to Safety of Geometric Design Consistency Measures for Rural Two-lane Highways". Transportation Research Record 1658, National Research Council, Washington, D. C. pp. 43-5. 
Ng, J.C.W. and Tarek S. 2004. "Effect of Geometric Design Consistency on Road Safety". Canadian Journal of Civil Engineering. 31.2; Proquest Science Journals, 218-227. 